\title{
Attitudes of a high-risk group of pregnant Saudi Arabian women to prenatal screening for chromosomal anomalies
}

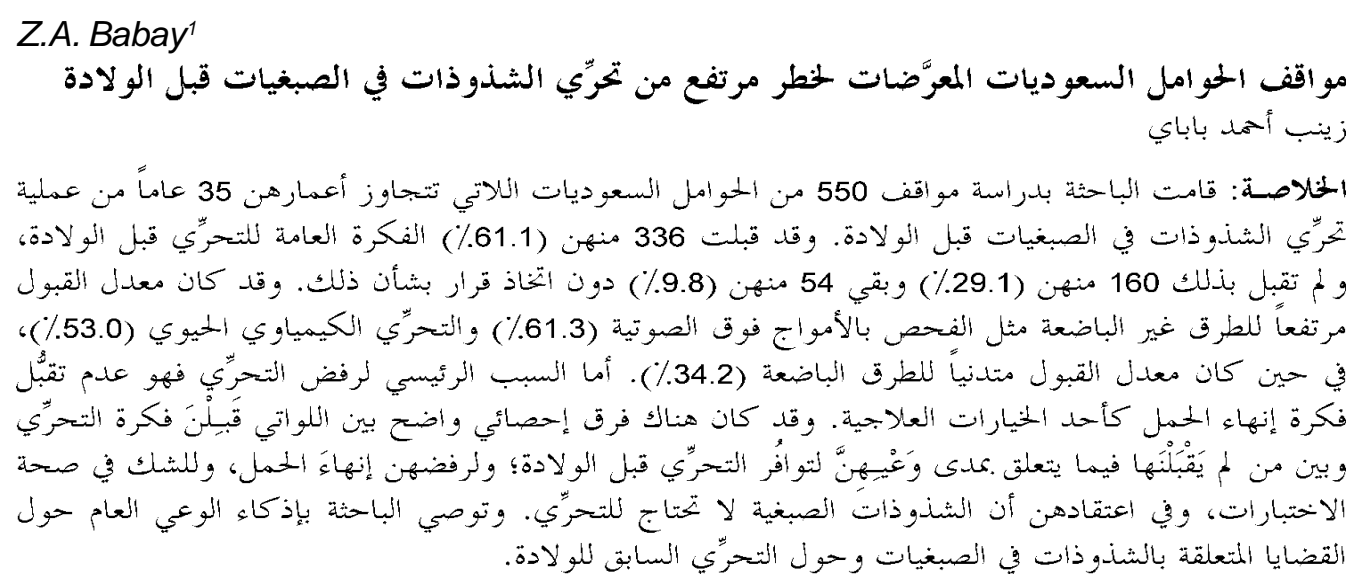

ABSTRACT The attitude of 550 pregnant Saudi Arabian women aged $>35$ years to prenatal screening for chromosomal anomalies was investigated. A total of 336 women $(61.1 \%)$ accepted the general idea of prenatal screening while 160 (29.1\%) did not; 54 women (9.8\%) were undecided. There was a high acceptance of non-invasive methods such as ultrasound (61.3\%) and biochemical screening (53.0\%) but a low acceptance of invasive methods (34.2\%). The main reason for refusal of screening was the unacceptability of termination of pregnancy as a treatment option. There were statistically significant differences between those who accepted the idea of screening and those who did not with regard to their awareness of the availability of prenatal screening, their rejection of pregnancy termination, their doubt of the accuracy of the tests and in their belief that chromosomal abnormalities need no be screened for.

\begin{abstract}
Attitudes d'un groupe de femmes enceintes saoudiennes à haut risque vis-à-vis du dépistage prénatal des anomalies chromosomiques

RÉSUMÉ On a examiné l'attitude de 550 femmes enceintes saoudiennes âgées de plus de 35 ans vis-à-vis du dépistage prénatal des anomalies chromosomiques. Au total, 336 femmes $(61,1 \%)$ acceptaient l'idée générale du dépistage prénatal tandis que 160 (29,1\%) ne l'acceptaient pas ; 54 femmes $(9,8 \%)$ étaient indécises. Il y avait une forte acceptation des méthodes noninvasives telles que l'échographie $(61,3 \%)$ et le dépistage biochimique $(53,0 \%)$ mais une faible acceptation des méthodes invasives $(34,2 \%)$. La raison principale du refus du dépistage était l'inacceptabilité de l'interruption de grossesse comme option thérapeutique. Il y avait des différences statistiquement significatives entre les femmes qui acceptaient l'idée du dépistage et celles qui ne l'acceptaient pas pour ce qui concerne la connaissance de l'existence du dépistage prénatal, leur rejet de l'interruption de grossesse, leur doute au sujet de l'exactitude des tests et leur opinion concernant le fait que les anomalies chromosomiques ne nécessitent pas de dépistage.
\end{abstract}

${ }^{1}$ Department of Obstetrics and Gynaecology, King Saud University, King Khaled University Hospital, Riyadh, Saudi Arabia.

Received: 30/04/03; accepted: 14/01/04

البحلة الصحية لشرق المتو سط، منظمة الصحة العالمية، البحلد العاشر، العددان ع-0، ع • • 


\section{Introduction}

Genetic diseases affect all populations and have been apparent since antiquity. In recent years many advances have been made in the field of prenatal screening for chromosomal anomalies. Techniques now available for such screening include second trimester biochemical screening ( $\alpha$-fetoprotein, $\beta$ human chorionic gonadotropin (HCG) and unconjugated estrogen), first trimester biochemical screening (pregnancy associated plasma protein A (PAPPA), and $\beta$ HCG), ultrasound fetal nuchal translucency measurement, in addition to the older invasive techniques such as amniocentesis and chorionic villus sampling. Some of the non-invasive methods have high sensitivity, especially if combined with ultrasound nuchal translucency measurement (90\% sensitivity and 3.1\% false positive rate) [1] in addition to causing no harm to the fetus. The use of these tests has resulted in a significant decrease in the prevalence of children with chromosomal abnormalities [2].

The incidence of Down syndrome in Saudi Arabia is 1.8 per 1000 live births [3], which is similar to the reported incidence in Hawaii but higher than the rest of the United States of America (10 per 10000 live births) [4]. Some modern Islamic opinion and rulings have accepted prenatal diagnosis and approved severe congenital anomalies and malformations per se as a reason for termination of pregnancy before ensoulment (120 days from conception or 134 days from last menstrual period) [5,6]. However, in spite of the availability of these screening tests, there are no reports in literature about their use in Saudi Arabia nor the awareness of Saudi Arabian women of such tests and their attitudes to them. Therefore, this study was carried out to assess the awareness and acceptance of such screening methods among pregnant Saudi Arabian women.

\section{Methods}

King Khalid University Hospital (KKUH) Riyadh, Saudi Arabia is the largest teaching hospital in the central region in Saudi Arabia, with an average delivery rate of 4500 babies per month. All pregnant women aged 35 years or older attending the Saturday afternoon antental clinic at KKUH between October 2002 and January 2003 were included in the study and were administered a questionnaire devised by the author. The questionnaire was conducted verbally and it included information on age, parity, personal or family history of a child with chromosomal anomalies, awareness of the availability of prenatal screening for such conditions and their acceptance of such screening in the next pregnancy, in addition to reasons for non-acceptance. None of the women refused to participate. Statistical analysis was done using SPSS, version 10 . The Student $t$-test was used to compare between variables and a $P$-value of $\leq 0.01$ was considered significant.

\section{Results}

A total of 1680 pregnant women attended the antental clinic during the study period. Of those, 550 (32.7\%) women were aged 35 years or older and were included in the study. The mean age and standard deviation (SD) was 37 (2.34) years (range 35-44 years) and mean parity was 4 (3.23) (range 1-7). In all, 284 women (51.6\%) knew about the availability of prenatal screening, 28 women (5.1\%) had a positive family history of a child with chromosomal anomalies and 13 women (2.4\%) had a history of giving birth to an affected child. A total of

لبحلة الصحية لُشرة المثو سط، منظمة الصحة العالمية، المبلد العاشر، العلددان ع-0، ع • • 
336 women (61.1\%) accepted the general idea of prenatal screening in the next pregnancy while 160 women (29.1\%) did not and 54 women (9.8\%) could not decide (Table 1). Among the women who accepted the idea of screening, $53.0 \%$ accepted the idea of biochemical screening, 61.3\% accepted the idea of ultrasound screening and $34.2 \%$ accepted the idea of invasive procedures such as amniocentesis and chorionic villus sampling.

Further questioning of the women who did not accept the idea of screening showed that $76 \%$ did not accept termination of pregnancy as an option in the event of an abnormal result, $22 \%$ did not accept screening in general as they doubted the accuracy of the tests, $19 \%$ did not believe that they would have an abnormal child and $6 \%$ did not believe chromosomal anomalies were an abnormality that should be screened for (Table 2).

Table 3 shows a comparison between those who accepted the idea of screening in pregnancy versus those who did not. There was a statistically significant difference be-

\begin{tabular}{lcr}
\hline \multicolumn{3}{l}{ Table 1 Characteristics of the study sample } \\
\hline Charactersitic & No. $(\boldsymbol{n}=\mathbf{5 5 0})$ & $\%$ \\
\hline $\begin{array}{l}\text { Had a positive personal } \\
\quad \text { history of a child with }\end{array}$ & & \\
$\quad$ chromosomal anomaly & 13 & 2.4 \\
Had a positive family & & \\
$\quad$ history of a child with & & \\
$\quad$ chromosomal anomaly & 28 & 5.1 \\
Was aware of the availability & & \\
$\quad$ of prenatal screening & 284 & 51.6 \\
Found screening: & & \\
$\quad \begin{array}{l}\text { Acceptable } \\
\text { Unacceptable }\end{array}$ & 336 & 61.1 \\
$\quad$ Undecided & 160 & 29.1 \\
& 54 & 9.8 \\
\hline
\end{tabular}

\begin{tabular}{lc}
\hline $\begin{array}{l}\text { Table } 2 \text { Reasons for finding prenatal } \\
\text { screening unacceptable }\end{array}$ & $\%$ \\
\hline Reason & 76 \\
\hline $\begin{array}{l}\text { Did not accept termination of } \\
\text { pregnancy as an option }\end{array}$ & 22 \\
$\begin{array}{l}\text { Doubted the accuracy of the tests } \\
\text { Did not believe that they would have a } \\
\text { child with chromosomal anomalies }\end{array}$ & 19 \\
$\begin{array}{l}\text { Did not believe chromosomal } \\
\text { abnormality was an abnormality } \\
\text { that should be screened for }\end{array}$ & \\
\hline
\end{tabular}

tween the 2 groups in their awareness of the availability of prenatal screening (57.7\% versus $42.1 \%)(P=0.0005)$, in their rejection of pregnancy termination (65.5\% versus $92.5 \%)(P=0.001)$, in their doubt of the accuracy of the tests $(8.9 \%$ versus $42.5 \%)(P=0.001)$ and in their belief that chromosomal abnormalities were not an abnormality that should be screened for $(0.3 \%$ versus $15.0 \%)(P=$ $0.001)$. There was no significant difference in acceptance or rejection of prenatal screening between those who had a positive family history of a child with chromosomal anomalies, those who had positive personal history of having a child with chromosomal anomalies, and those who believed that they would not have a child with chromosomal anomalies.

A comparison was made between the women who had positive family history of a child with a chromosomal anomaly, those with a positive personal history of having a child with a chromosomal anomaly, and those who did not have any such history (Table 4). There was a statistically significant difference between the 3 groups in acceptance of termination of pregnancy (75.0\%, 69.2\% and $76.2 \%$ respectively) $(P=0.001)$, in the belief in the possibility

البلة الصحية لشرق المتوبط، منظمة الصحة العالمية، البجلد العاشر، العددان ع-0، ع + •؟ 


\begin{tabular}{|c|c|c|c|c|c|c|c|}
\hline \multicolumn{7}{|c|}{ Eastern Mediterranean Health Journal, Vol. 10, Nos 4/5, 2004} & 525 \\
\hline \multicolumn{8}{|c|}{$\begin{array}{l}\text { Table } 3 \text { Comparison of women who accepted the idea of prenatal screening for chromosomal } \\
\text { abnormalities and those who did not }\end{array}$} \\
\hline \multirow[t]{2}{*}{ Variable } & \multicolumn{2}{|c|}{$\begin{array}{l}\text { Accepted } \\
\text { screening } \\
(n=336)\end{array}$} & \multicolumn{2}{|c|}{$\begin{array}{l}\text { Did not accept } \\
\text { screening/was } \\
\text { undecided } \\
\quad(n=214)\end{array}$} & \multirow[t]{2}{*}{$\begin{array}{l}\text { Odds } \\
\text { ratio }\end{array}$} & \multirow[t]{2}{*}{$95 \% \mathrm{Cl}$} & \multirow[t]{2}{*}{$P$-value } \\
\hline & No. & $\%$ & No. & $\%$ & & & \\
\hline $\begin{array}{l}\text { Had a positive family } \\
\text { history of a child with } \\
\text { chromosomal anomaly }\end{array}$ & 20 & 6.9 & 8 & 3.7 & 1.63 & $0.67-4.11$ & 0.3407 \\
\hline $\begin{array}{l}\text { Had a positive personal } \\
\text { history of a child with } \\
\text { chromosomal anomaly }\end{array}$ & 8 & 2.4 & 5 & 2.3 & 1.02 & $0.29-4.02$ & 0.7992 \\
\hline $\begin{array}{l}\text { Was aware of the } \\
\text { availability of prenatal } \\
\text { screening }\end{array}$ & 194 & 57.7 & 90 & 42.1 & 1.88 & $1.31-2.70$ & $0.0005^{\star \star}$ \\
\hline $\begin{array}{l}\text { Did not accept termination } \\
\text { of pregnancy as an option }\end{array}$ & 220 & 65.5 & 198 & 92.5 & 0.15 & $0.08-0.28$ & $0.001^{* *}$ \\
\hline $\begin{array}{l}\text { Doubted the accuracy of } \\
\text { prenatal screening tests }\end{array}$ & 30 & 8.9 & 91 & 42.5 & 0.13 & $0.08-0.22$ & $0.001^{* *}$ \\
\hline $\begin{array}{l}\text { Did not believe that they } \\
\text { would have a child with } \\
\text { chromosomal anomalies }\end{array}$ & 56 & 16.7 & 49 & 22.9 & 0.67 & $0.43-1.06$ & 0.0889 \\
\hline $\begin{array}{l}\text { Did not believe chromosomal } \\
\text { anomaly was an abnormality } \\
\text { that should be screened for }\end{array}$ & 1 & 0.3 & 32 & 15.0 & 0.02 & $0.0-0.1$ & $0.001^{* *}$ \\
\hline
\end{tabular}

${ }^{*}$ Statistically significant at $\mathrm{P} \leq 0.01$.

$\mathrm{Cl}=$ confidence interval.

of delivering a child with chromosomal anomalies $(64.3 \%, 84.6 \%$ and $14.9 \%$ respectively) $(P=0.001)$, in the acceptance of chromosomal anomalies as an abnormality that should be screened for (7.1\%, 38.5\% and $5.1 \%$ respectively) $(P=0.001)$, in the acceptance of biochemical screening during pregnancy (71.4\%, 53.8\% and $29.7 \%$ respectively) $(P=0.001)$, in the acceptance of ultrasound screening during pregnancy $(71.4 \%$, $61.5 \%$ and $25.5 \%$ respectively) ( $P=$ 0.001 ), and in the acceptance of an invasive investigation $(25.0 \%, 100.0 \%, 43.4 \%$ respectively) $(P=0.001)$.

\section{Discussion}

The old adage that prevention is better than cure applies as much to genetic as to acquired diseases. Primary prevention of abnormal genotypes would need to act prior to conception. Prenatal diagnosis with selective termination (secondary prevention) alters the birth frequency of the condition but is really only a holding measure pending the development of primary prevention of genetic disease. Currently the only primary prevention available is pre-implantation genetic diagnosis which requires in vitro

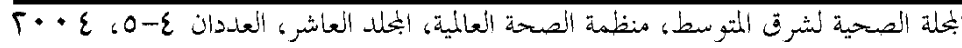




\begin{tabular}{|c|c|c|c|c|c|c|c|}
\hline \multirow{2}{*}{$\begin{array}{l}\text { Variable } \\
\begin{array}{l}\text { Accepted the idea of } \\
\text { prenatal screening }\end{array}\end{array}$} & \multicolumn{2}{|c|}{$\begin{array}{l}\text { Positive family } \\
\text { history }(n=28) \\
\text { No. } \quad \%\end{array}$} & \multicolumn{2}{|c|}{$\begin{array}{l}\text { Positive personal } \\
\text { history }(n=13)\end{array}$} & \multicolumn{2}{|c|}{$\begin{array}{l}\text { No history } \\
(n=509)\end{array}$} & $P$-value \\
\hline & 20 & 71.4 & 8 & 61.5 & 308 & 60.5 & 0.263 \\
\hline $\begin{array}{l}\text { Was aware of the availability } \\
\text { prenatal screening }\end{array}$ & 15 & 53.6 & 10 & 76.9 & 259 & 50.9 & 0.0639 \\
\hline $\begin{array}{l}\text { Did not accept termination } \\
\text { of pregnancy as an option }\end{array}$ & 21 & 75.0 & 9 & 69.2 & 388 & 76.2 & $0.0019^{* *}$ \\
\hline $\begin{array}{l}\text { Doubted the accuracy of } \\
\text { prenatal screening tests }\end{array}$ & 5 & 17.9 & 3 & 23.1 & 113 & 22.2 & 0.86 \\
\hline $\begin{array}{l}\text { Did not believe that they } \\
\text { would have a child with } \\
\text { chromosomal anomalies }\end{array}$ & 18 & 64.3 & 11 & 84.6 & 76 & 14.9 & $0.001^{* *}$ \\
\hline $\begin{array}{l}\text { Did not believe chromosomal } \\
\text { anomaly was an abnormality } \\
\text { that should be screened for }\end{array}$ & 2 & 7.1 & 5 & 38.56 & 26 & 5.1 & $0.001^{* *}$ \\
\hline $\begin{array}{l}\text { Accepted the idea of biochemical } \\
\text { screening }\end{array}$ & 20 & 71.4 & 7 & 53.8 & 151 & 29.7 & $0.001^{* *}$ \\
\hline $\begin{array}{l}\text { Accepted the idea of ultrasound } \\
\text { screening }\end{array}$ & 20 & 71.4 & 8 & 61.5 & 130 & 25.5 & $0.001^{\star *}$ \\
\hline $\begin{array}{l}\text { Accepted the idea of invasive } \\
\text { screening (aminocentesis and } \\
\text { chorionic villus sampling }\end{array}$ & 7 & 25.0 & 13 & 100.0 & 221 & 43.4 & $0.001^{* *}$ \\
\hline
\end{tabular}

${ }^{*}$ Statistically significant at $\mathrm{P} \leq 0.01$.

fertilization and this is not suitable as a screening test. The principle for any test to be used for screening populations is that it should be sensitive, relatively specific and harmless. In addition, the disorder screened for should be of appreciable frequency and early diagnosis should be an advantage. In our study almost two-thirds (61.1\%) of the women questioned accepted the idea of screening. Of those accepting the idea of screening, all accepted ultrasound screening, probably because it is part of the antenatal care in Saudi Arabia and is therefore familiar to them and does not carry any risk of abortion. The acceptance rate for biochemical screening was lower $(53.0 \%)$. This rate is similar to the reported acceptance rate in other parts of the world $[7,8]$. The acceptance rate of invasive procedures was much lower (34.2\%) probably because as it carries the risk of abortion. On the other hand, 29.1\% of the women did not accept the idea of screening; the main reason was that they did not accept termination of pregnancy as a treatment option.

Factors such as socioeconomic structure, education and religion affect the

البحلة الصحية لشرق المثتوسط، منظمة الصحة العالمية، البحلد العاشر، العددان ع-0، ع • • 
acceptability of prenatal diagnosis. These factors are very important in Saudi Arabia as all Saudi Arabians are Muslims and high parity is a characteristic feature of the community. At the same time, the physician's attitude towards such tests is important as they share the same religious background.

Public awareness of the risks and difficulties facing a child with chromosomal anomalies and the effect on their future health and living is of great importance for acceptance of prenatal screening. In our study $19 \%$ of the women believed that they would not have a child with chromosomal anomalies although, because of their age (> 35 years), this was a high-risk population for certain such conditions. In addition, the difference between those who accepted screening and those who did not was statistically significant in regards to their awareness of the availability of prenatal screening and in their belief in the accuracy of the tests (Table 3 ), which reflects a lack of health knowledge.

From this study we conclude that combined biochemical screening and ultrasound nuchal translucency are the most acceptable prenatal genetic screening tests for Saudi Arabian women bearing in mind the religious and social background. Prenatal diagnosis of such anomalies is important for both the parents and physicians even if termination is not undertaken. Physicians should be encouraged to offer these test and to give appropriate counseling as this high-risk group constituted $32.7 \%$ of the women attending the antental clinic. Public awareness should also be raised about the issues of genetic abnormalities and prenatal screening until suitable primary prevention is available.

\section{References}

1. Benn PA et al. Combined second trimester biochemical and ultrasound screening for Down syndrome. Obstetrics and gynecology, 2002, 100(6):1168-76.

2. Cheffins $T$ et al. The impact of maternal serum screening on the birth prevalence of Down syndrome and the use of amniocentesis and chorionic villus sampling in south Australia. British journal of obstetrics and gynaecology, 2000, 107(12):1453-9.

3. Niazi MA et al. Down's syndrome in Saudi Arabia: incidence and cytogenetics. Human heredity, 1995, 45(2):65-9.

4. Forrester MB, Merz RD. Epidemiology of Down syndrome (trisomy 21) in Hawaii, 1986-97. Teratology, 2002, 65(5):20712.
5. Ghanem I. [Abortion as a necessity]. Al Faisal medical journal, 1984, 9:6-15 [in Arabic].

6. [Regarding termination of pregnancy for congenital abnormality (No. 4)]. Twelfth Session of the Moslem World League Conference of Jurists, Mecca 10-17 February 1990 [In Arabic].

7. DeGraaf IM et al. Women's preference in Down syndrome screening. Prenatal diagnosis, 2002, 22(7):624-9.

8. Lam YH et al. Acceptability of serum screening as an alternative to cytogenetic diagnosis of Down syndrome among women 35 years or older in Hong Kong. Prenatal diagnosis, 2000, 20(6): 487-90.

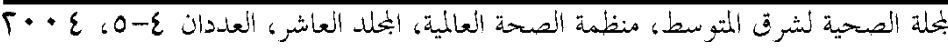

